\title{
Use of sodium bicarbonate in out-of- hospital cardiac arrest: a systematic review and meta-analysis
}

\author{
Mohammed S. Alshahrani ${ }^{1}$ and Hassan W. Aldandan² ${ }^{*}$ (D)
}

\begin{abstract}
Background: Out-of-hospital cardiac arrest (OHCA) is a common cause of death worldwide (Neumar et al., Circulation 122:S729-S767, 2010), affecting about 300,000 persons in the USA on an annual basis; $92 \%$ of them die (Roger et al., Circulation 123:e18-e209, 2011). The existing evidence about the use of sodium bicarbonate (SB) for the treatment of cardiac arrest is controversial. We performed this study to summarize the evidence about the use of SB in patients with out-of-hospital cardiac arrest (OHCA).
\end{abstract}

Methods: We searched PubMed, Scopus, EBSCO, Web of Science, and Cochrane Library, until June 2019, for randomized controlled trials (RCTs) and observational studies that used SB in patients with OHCA. Outcomes of interest were the rate of survival to discharge, return of spontaneous circulation (ROSC), sustained ROSC, and good neurological outcomes at discharge. Odds ratio (OR) with their 95\% confidence interval (Cl) were pooled in a random or fixed meta-analysis model.

Results: A total of 14 studies (four RCTs and 10 observational studies) enrolling 28,412 patients were included; of them, eight studies were included in the meta-analysis. The overall pooled estimate did not favor SB or control in terms of survival rate at discharge $(\mathrm{OR}=0.66,95 \% \mathrm{Cl}[0.18,2.44], p=0.53)$ and $\mathrm{ROSC}$ rate $(\mathrm{OR}=1.54,95 \% \mathrm{Cl}[0.38,6.27], p=0.54)$, while the pooled estimate of two studies showed that SB was associated with less sustained $\mathrm{ROSC}(\mathrm{OR}=0.27,95 \% \mathrm{Cl}$ $[0.07,0.98], p=0.045)$ and good neurological outcomes at discharge ( $\mathrm{OR}=0.12,95 \% \mathrm{Cl}[0.09,0.15], p<0.01)$.

Conclusion: The current evidence demonstrated that SB was not superior to the control group in terms of survival to discharge and return of spontaneous circulation. Further, SB was associated with lower rates of sustained ROSC and good neurological outcomes.

Keywords: Sodium bicarbonate, Out-of-hospital cardiac arrest, Meta-analysis

\section{Introduction}

Out-of-hospital cardiac arrest (OHCA) is a common cause of death worldwide [1], affecting about 300,000 persons in the USA on an annual basis; 92\% of them die [2]. An OHCA is defined as cessation of the mechanical activity of the heart outside the hospital with absence of

\footnotetext{
* Correspondence: hwaldandan@iau.edu.sa

${ }^{2}$ Department of Critical Care Medicine, King Fahad Hospital of the University, Alkhobar, Saudi Arabia

Full list of author information is available at the end of the article
}

circulation signs. Most OHCA events are of cardiac origin (70 to 85\%), while some cases occur due to non-cardiac causes, such as posttraumatic, drug overdose, drowning, primary respiratory arrest, electrocution, and asphyxia [3].

In an attempt to restore cardiopulmonary functions and achieve good neurological outcomes, the advanced life support (ALS) guidelines have been extensively developed and applied internationally. Sodium bicarbonate (SB) has been routinely used during cardiopulmonary resuscitation (CPR) in cardiac arrest to correct metabolic

C C The Author(s). 2021 Open Access This article is licensed under a Creative Commons Attribution 4.0 International License, which permits use, sharing, adaptation, distribution and reproduction in any medium or format, as long as you give appropriate credit to the original author(s) and the source, provide a link to the Creative Commons licence, and indicate if changes were made. The images or other third party material in this article are included in the article's Creative Commons licence, unless indicated otherwise in a credit line to the material. If material is not included in the article's Creative Commons licence and your intended use is not permitted by statutory regulation or exceeds the permitted use, you will need to obtain permission directly from the copyright holder. To view a copy of this licence, visit http://creativecommons.org/licenses/by/4.0/ The Creative Commons Public Domain Dedication waiver (http://creativecommons.org/publicdomain/zero/1.0/) applies to the data made available in this article, unless otherwise stated in a credit line to the data. 
acidosis. Earlier ALS guidelines have recommended the use of SB in cardiac arrest, and it was frequently used until the mid-1980s [4, 5]. However, the American Heart Association (AHA) guidelines in 1986 raised many doubts regarding the safety and efficacy of SB [6]. The following guidelines in 1992 [7] and 2000 [8] discouraged its use. Moreover, SB had been shown to cause hypernatremia, alkalosis, and excess carbon dioxide during CPR [9]. For these reasons, the updated AHA guidelines in 2010 did not recommend SB administration in cardiac arrest patients [1], except for hyperkalemia or tricyclic antidepressant overdose or cases of severe cardiotoxicity $[10,11]$.

The existing evidence about the use of $\mathrm{SB}$ for the treatment of cardiac arrest is controversial. A previous study suggested that early and more frequent use of SB resulted in favorable short and long outcomes [12]. Another recent study showed that SB use led to an increase in return of spontaneous circulation (ROSC) rate [13]. On the other hand, other reports failed to establish beneficial effects of SB in cardiac arrest [14-16].

In this systematic review and meta-analysis, we aimed to assess the effect of SB on the survival rate to hospital discharge, ROSC, and good neurological outcomes at discharge in patients with OHCA.

\section{Methods}

We performed all steps of this systematic review in strict accordance with Cochrane Handbook of Systematic Reviews and Meta-analysis [17]. We also followed the preferred reporting items for systematic reviews and metaanalyses (PRISMA statement guidelines) during drafting our manuscript [18].

\section{Literature search}

We searched PubMed, Scopus, EBSCO, Web of Science, and the Cochrane Central Register of controlled trials (CENTRAL) to identify relevant studies, until June 2019, without any language restrictions. The following search queries were used independently or in combination according to the medical subject headings (MESH) ("sodium bicarbonate", "bicarbonate", "NaHCO3, "cardiac arrest", and "cardiopulmonary resuscitation"). We searched ClinicalTrials.gov to identify additional relevant studies. Furthermore, we hand-searched references of the most relevant articles.

\section{Eligibility criteria}

We included studies that met the following criteria:

- Study design: randomized controlled trials (RCTs) and observational studies.

- Population: adult patients with OHCA.
- Intervention: SB administration during cardiopulmonary resuscitation.

- Comparator: no administration of SB during cardiopulmonary resuscitation.

- Outcomes: primary outcome measured was the survival rate to hospital discharge and secondary outcomes were ROSC, sustained ROSC defined as the restoration of a palpable pulse $\geq 20 \mathrm{~min}$, and good neurological outcome at discharge defined as cerebral performance category (CPC) 1 or 2 or modified Rankin scale of 3 or less.

We excluded animal studies, reviews, case reports, case series, conference abstracts, and duplicate references.

\section{Study selection}

Two authors independently applied the selection criteria. Eligibility screening was conducted in two steps: (a) title and abstract screening for matching the inclusion criteria and (b) full-text screening for eligibility to metaanalysis using a standardized Excel spreadsheet.

\section{Data extraction}

Data extraction was carried out by two researchers, while a third researcher resolved any disputes between the two main researchers. The data collected were the first author's name, publication year, country, study design, interventions, number of participants, age, gender, study period, and outcomes of interest.

\section{Risk of bias assessment}

We used the Cochrane risk of bias (ROB) assessment tool [19], which includes five types of bias: selection bias (sequence generation and allocation concealment), performance bias (blinding of participants and investigators), detection bias (blinding of outcome assessors), attrition bias (incomplete outcome data), and reporting bias (selective outcome reporting). Each study is classified in each domain as low, high, or unclear risk of bias. We evaluated the quality of observational studies using the Newcastle Ottawa scale (NOS) [20], which assesses studies based on three domains: (a) selection of the study subjects, (b) comparability of groups on demographic characteristics and important potential confounders, and (c) ascertainment of the prespecified outcome (exposure/treatment).

\section{Data analysis and assessment of heterogeneity}

The analyses were performed using the $\mathrm{R}$ software for Windows (version 3.5-3, meta-package). We calculated the odds ratio (OR) and 95\% confidence intervals (CI) for each outcome. A $p$-value $<0.05$ was considered statistically significant. Heterogeneity was assessed by visual inspection of the forest plots and measured by $Q$ statistic 
and $I^{2}$ statistic. Significant statistical heterogeneity was indicated by $Q$ statistic $p$-value less than 0.1 or by $I^{2}$ more than $50 \%$. In the case of significant heterogeneity, a random effect model was employed. Otherwise, the fixed effect model was used. Subgroup analysis and sensitivity analysis were used to resolve the heterogeneity.

\section{Results}

\section{Search strategy results}

Our search retrieved 1746 unique citations. Twenty-six articles were retrieved and screened for eligibility to the systematic review and meta-analysis. Of these, 12 articles were excluded, and 14 studies were included in the systematic review. The PRISMA flow diagram of study selection is shown in Fig. 1.

\section{Baseline characteristics and risk of bias}

Fourteen studies (four RCTs [14, 15, 21, 22] and 10 observational studies [12, 13, 16, 23-29]) enrolling 28,412 patients were included; of them, eight studies were included in the meta-analysis. All articles were published in English from 1989 to 2018. Countries included were the USA (five studies), Taiwan (two studies), Korea (two studies), Canada (one study), China (one study), Colombia (one study), Norway (one study), and Belgium (one study). A summary of the design and baseline characteristics of enrolled patients is presented in Table 1. The included four RCTs reported that the enrolled patients were randomly allocated to different study groups, but only three studies reported how randomization was performed. One used computer-generated random number [14], another study used blinded packaging by the manufacturer [15], and the third generated a random sequence using the Excel software [21]. All RCTs were at low risk of bias in terms of attrition bias and reporting bias, while blinding was unclear in the four RCTs. Observational cohort studies achieved a moderate quality according to the NOS checklist. A summary of risk of bias assessment of RCTs and observational studies is shown in supplementary file 1 .

\section{Outcomes}

\section{Survival to discharge}

Seven studies (four RCTs and three observational studies) reported on the survival rate after discharge from hospital, with a total of 16,213 patients. There was no

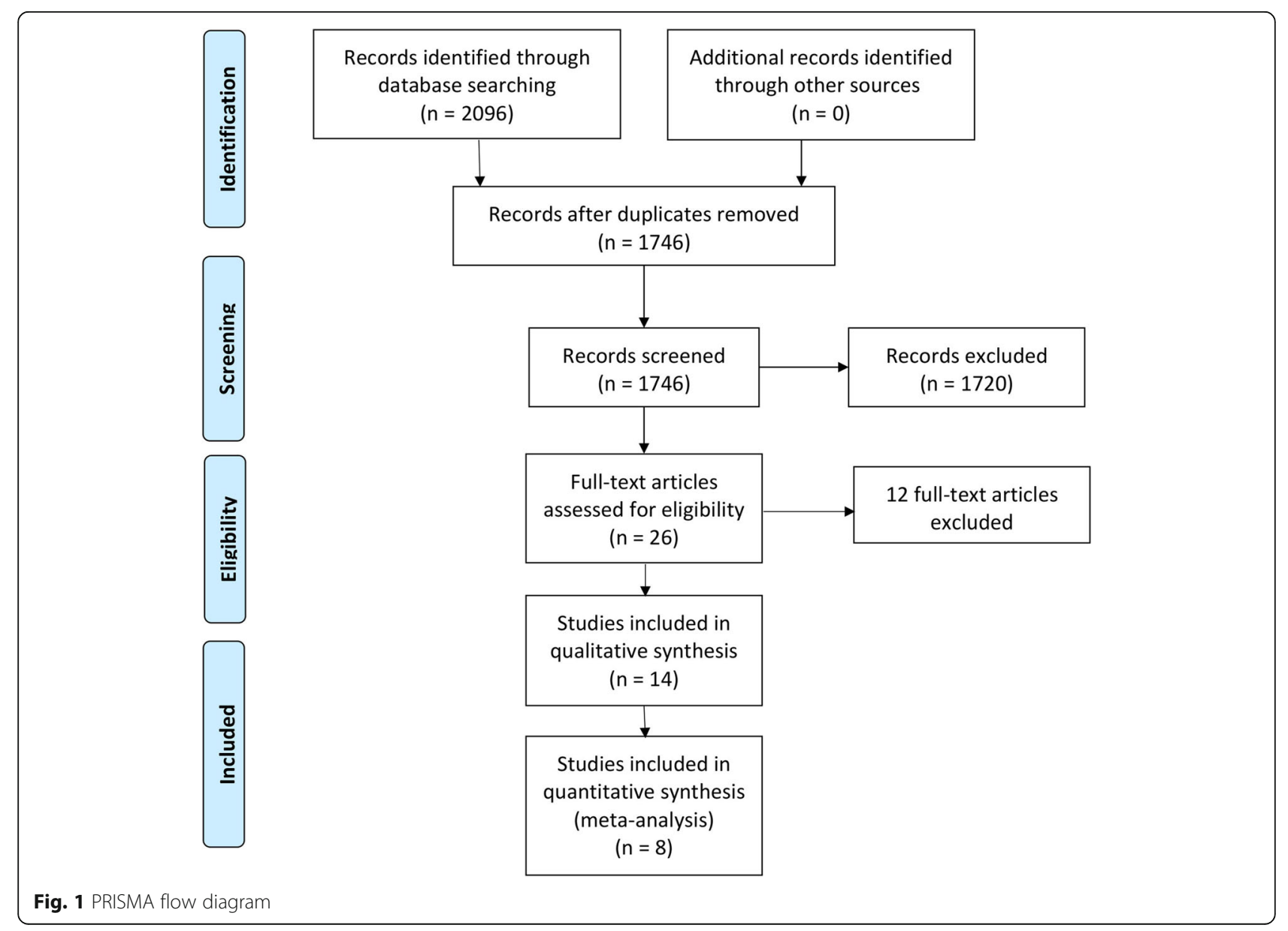


Table 1 Summary of included studies

\begin{tabular}{|c|c|c|c|c|c|c|c|}
\hline $\begin{array}{l}\text { Author, } \\
\text { year }\end{array}$ & Country & Study design & $\begin{array}{l}\text { Interventions, No. of } \\
\text { patients }\end{array}$ & $\begin{array}{l}\text { Mean age, SD or } \\
\text { range (BS vs. } \\
\text { control) }\end{array}$ & $\begin{array}{l}\text { Sex, male } \\
\text { (BS vs. } \\
\text { control) }\end{array}$ & $\begin{array}{l}\text { Study } \\
\text { duration }\end{array}$ & Main findings \\
\hline $\begin{array}{l}\text { Ahn et al. } \\
2018 \text { [21] }\end{array}$ & Korea & $\mathrm{RCT}$ & $\begin{array}{l}\text { SB }(n=25) \text { vs. placebo }(n= \\
25)\end{array}$ & $\begin{array}{l}65.5(16.4) / 64.1 \\
(15.4)\end{array}$ & $18 / 21$ & $\begin{array}{l}\text { January- } \\
\text { December } \\
2015\end{array}$ & $\begin{array}{l}\text { No difference between SB and } \\
\text { placebo in sustained ROSC } \\
\text { and survival }\end{array}$ \\
\hline $\begin{array}{l}\text { Chen et al. } \\
2018 \text { [23] }\end{array}$ & Taiwan & $\begin{array}{l}\text { Population- } \\
\text { based cohort } \\
\text { study }\end{array}$ & $\begin{array}{l}\text { SB }(n=1885) \text { vs. control } \\
(n=3704)\end{array}$ & $\begin{array}{l}\text { Older than } 18 \\
\text { years }\end{array}$ & $1140 / 2379$ & 1997-2012 & $\begin{array}{l}\text { Positive association between } \\
\text { SB and survival }\end{array}$ \\
\hline $\begin{array}{l}\text { Kawano } \\
\text { et al. } 2017 \\
{[24]}\end{array}$ & Columbia & $\begin{array}{l}\text { Population- } \\
\text { based } \\
\text { observational } \\
\text { study }\end{array}$ & $\begin{array}{l}\text { SB }(n=5165) \text { vs. control } \\
(n=8700)\end{array}$ & $\begin{array}{l}65(52-77) / 68 \\
(56-80)\end{array}$ & $3682 / 5779$ & $2005-2016$ & SB had less survival \\
\hline $\begin{array}{l}\text { Chung et al. } \\
2015 \text { [25] }\end{array}$ & China & $\begin{array}{l}\text { Retrospective } \\
\text { observational } \\
\text { study }\end{array}$ & $\begin{array}{l}\text { SB }(n=74) \text { vs. control }(n= \\
415)\end{array}$ & $\begin{array}{l}65.9(22.7) / 72.8 \\
(19.9)\end{array}$ & $52 / 237$ & $\begin{array}{l}\text { March- } \\
\text { December } \\
2013\end{array}$ & $\begin{array}{l}\text { SB had a higher percentage of } \\
\text { ROSC and survival }\end{array}$ \\
\hline $\begin{array}{l}\text { Weng et al. } \\
2013 \text { [26] }\end{array}$ & Taiwan & $\begin{array}{l}\text { Retrospective } \\
\text { cohort }\end{array}$ & $\begin{array}{l}\text { SB }(n=30) \text { vs. control }(n= \\
62)\end{array}$ & $65 / 70.5$ & $19 / 47$ & $\begin{array}{l}\text { January 1- } \\
\text { December } \\
2009\end{array}$ & $\begin{array}{l}\text { SB did not improve rate of } \\
\text { ROSC in prolonged (> } 15 \mathrm{~min} \text { ) } \\
\text { cardiac arrest }\end{array}$ \\
\hline $\begin{array}{l}\text { Vukmir and } \\
\text { Katz } 2006 \\
{[15]}\end{array}$ & USA & $\mathrm{RCT}$ & $\begin{array}{l}\text { SB }(n=420) \text { vs. control }(n= \\
372)\end{array}$ & $\begin{array}{l}67.37(15.29) / \\
67.16(14.96)\end{array}$ & & 1994-1998 & $\begin{array}{l}\text { Overall survival 13.9\% (110/ } \\
\text { 792), no difference between } \\
\text { groups }\end{array}$ \\
\hline $\begin{array}{l}\text { Dybvik et al. } \\
1995[14]\end{array}$ & Norway & $\mathrm{RCT}$ & $\begin{array}{l}\text { SB }(n=245) \text { vs. saline }(n= \\
257)\end{array}$ & $236 / 266$ & - & 1987-1994 & $\begin{array}{l}\text { SB therapy had no effect on } \\
\text { outcome }\end{array}$ \\
\hline $\begin{array}{l}\text { Stiell et al. } \\
1995[28]\end{array}$ & Canada & $\begin{array}{l}\text { Observational } \\
\text { cohort study }\end{array}$ & $\begin{array}{l}\text { BS vs. atropine, } \mathrm{Ca}, \\
\text { lidocaine, bretylium, } \\
\text { procainamide, } n=529\end{array}$ & 19 to 98 & - & 2 years & $\begin{array}{l}\text { Logistic regression did not } \\
\text { show association between SB } \\
\text { and survival }\end{array}$ \\
\hline $\begin{array}{l}\text { Aufderheide } \\
\text { et al. } 1992 \\
\text { [16] }\end{array}$ & USA & $\begin{array}{l}\text { Retrospective } \\
\text { chart review }\end{array}$ & $\begin{array}{l}\text { SB }(n=215) \text { vs. No SB ( } n= \\
58)\end{array}$ & $67(13) / 65$ (12) & $143 / 39$ & $\begin{array}{l}1982- \\
1984 .\end{array}$ & $\begin{array}{l}\text { No association between SB } \\
\text { and survival }\end{array}$ \\
\hline $\begin{array}{l}\text { Weaver et al. } \\
1990[22]\end{array}$ & USA & $\mathrm{RCT}$ & $\begin{array}{l}\text { SB }(n=224) \text {, lidocaine ( } n= \\
106) \text {, epi }(n=93)\end{array}$ & $\begin{array}{l}65.6(12.6) / 67.5 \\
(13.2) / 66.3(1.3)\end{array}$ & $177 / 89 / 77$ & 1983-1985 & $\begin{array}{l}\text { Higher survival with SB } \\
\text { infusion }\end{array}$ \\
\hline $\begin{array}{l}\text { Kim et al. } \\
2016 \text { [13] }\end{array}$ & Korea & $\begin{array}{l}\text { Observational } \\
\text { study }\end{array}$ & SB $(n=771)$ & $68(52-77)$ & 375 & 2008-2013 & $\begin{array}{l}\text { SB was associated with } \\
\text { increased ROSC. }\end{array}$ \\
\hline $\begin{array}{l}\text { Bar-Joseph } \\
\text { et al. } 2005 \\
{[12]}\end{array}$ & USA & $\begin{array}{l}\text { Retrospective } \\
\text { study }\end{array}$ & SB $(n=2122)$ & - & - & $\begin{array}{l}1990- \\
1992\end{array}$ & $\begin{array}{l}\text { Earlier and more frequent use } \\
\text { of SB associated with higher } \\
\text { ROSC }\end{array}$ \\
\hline $\begin{array}{l}\text { Bar-Joseph } \\
\text { et al. } 2002 \\
\text { [27] }\end{array}$ & USA & $\begin{array}{l}\text { Retrospective } \\
\text { study }\end{array}$ & SB $(n=2915)$ & - & 1955 & 1990-1992. & $\begin{array}{l}\text { SB given in } 54 \% \text { of cases, use } \\
\text { increased with ACLS duration }\end{array}$ \\
\hline $\begin{array}{l}\text { Delooz and } \\
\text { Lewi } 1989 \\
\text { [29] }\end{array}$ & Belgium & $\begin{array}{l}\text { Retrospective } \\
\text { data analysis }\end{array}$ & SB & - & - & - & $\begin{array}{l}\mathrm{SB}>1 \mathrm{mEq} / \mathrm{kg} \text { associated } \\
\text { with poor outcome }\end{array}$ \\
\hline
\end{tabular}

$R C T$ randomized controlled trial, $S B$ sodium bicarbonate, $R O S C$ return of spontaneous circulation, CPR cardiopulmonary resuscitation, $A C L S$ advanced cardiac life support

significant difference between $\mathrm{SB}$ or control $(\mathrm{OR}=0.66$, 95\% CI [0.18, 2.44], $p=0.53)$, Fig. 2a.

This effect size was consistent with subgroup analysis of RCTs $(\mathrm{OR}=1.04,95 \% \mathrm{CI}[0.72,1.50], p=0.85)$ and observational studies $(\mathrm{OR}=0.37,95 \% \mathrm{CI}[0.04,3.21], p=0.37)$. Significant heterogeneity was detected $\left(I^{2}=97 \% ; p<0.01\right)$ which was best resolved by excluding the study by Kawano et al. [24] $\left(\mathrm{OR}=1.06,95 \%\right.$ CI $[0.82,1.37], p=0.65, I^{2}=6 \% ; p=$ 0.38), Fig. 2b.

\section{Return of spontaneous circulation (ROSC)}

Five studies (one RCT and four observational studies) reported on the rate of ROSC, with a total of 20,085 patients. The overall effect size showed no significant difference between $\mathrm{SB}$ and control $(\mathrm{OR}=1.54,95 \% \mathrm{CI}$ $[0.38,6.27], p=0.54)$, Fig. 3 . This effect size was consistent with subgroup analysis according to study design: $\mathrm{RCT}(\mathrm{OR}=0.43,95 \% \mathrm{CI}[0.09,1.97], p=0.28)$ and observational studies $(\mathrm{OR}=2.01,95 \% \mathrm{CI}[0.43,9.43], p=0.38)$. 


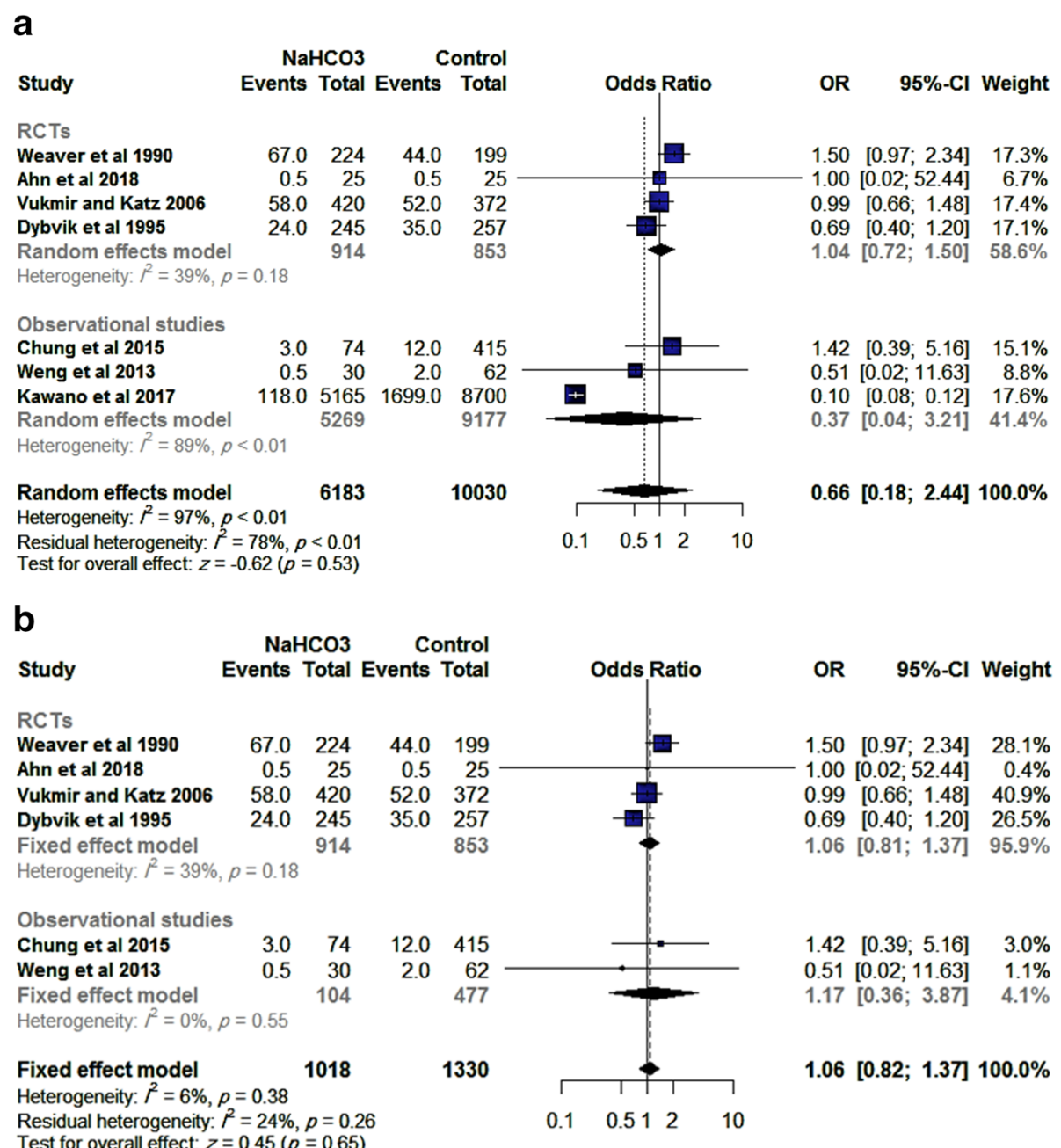

Fig. 2 a Effect of (SB) administration on survival to discharge. $\mathbf{b}$ Effect of (SB) administration on survival to discharge after resolution of heterogeneity

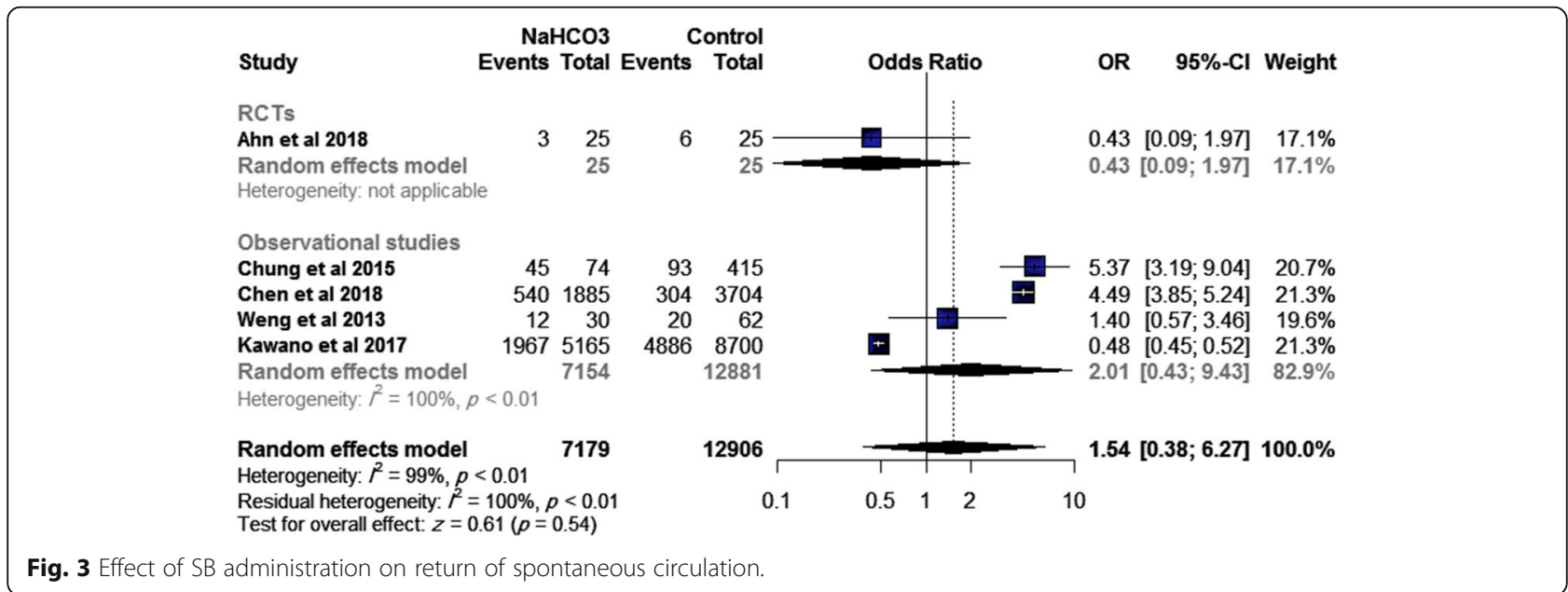


Significant heterogeneity was detected $\left(I^{2}=99 \% ; p<0.01\right)$ which could not be resolved by sensitivity analysis.

\section{Sustained ROSC (> 20 min)}

The pooled effect size of two studies (one RCT and one observational study, $n=86$ patients) showed that SB was associated with a lower incidence of sustained ROSC than control $(\mathrm{OR}=0.27,95 \% \mathrm{CI}[0.07,0.98], p=0.045)$, Fig. 4, while this effect size was inconsistent with subgroup analysis of RCT $(\mathrm{OR}=0.22,95 \% \mathrm{CI}[0.02,2.11]$, $p=0.19)$ and observational study $(\mathrm{OR}=0.30,95 \% \mathrm{CI}$ $[0.06,1.43], p=0.78)$. No significant heterogeneity was observed $\left(I^{2}=0 \%, p=0.83\right)$.

\section{Good neurological outcomes at discharge}

The pooled effect size of two studies (one RCT and one observational study, $n=13915$ ) showed that SB was associated with a lower incidence of good neurological outcomes at hospital discharge than control $(\mathrm{OR}=0.12,95 \%$ CI $[0.09,0.15], p<0.01)$, Fig. 5. This effect size was consistent with subgroup analysis of the observational study $(\mathrm{OR}=0.12,95 \% \mathrm{CI}[0.09,0.15], p<0.01)$; however, the RCT did not favor either group (OR=1.00, $95 \% \mathrm{CI}[0.02$, 52.44], $p=1.00)$. No significant heterogeneity was observed $\left(I^{2}=12 \%, p=0.29\right)$.

\section{Narrative review of other studies}

Kim et al. conducted an observational study in 2016 to assess the relationship between BS and incidence of ROSC and found that SB and its cumulative dose were significantly related to a higher incidence of ROSC within 20 $\mathrm{min}$, and this relation kept true after adjustment with multivariable conditional logistic regression analysis [13]. BarJoseph et al. in 2002 conducted a retrospective study based on brain resuscitation clinical trial and concluded that, when bicarbonate was used, it was probably used late, and suggested that, because of development of severe metabolic acidosis, bicarbonate administration should start early [27].
Another study by Bar-Joseph et al. in 2005 reported a survival rate of $33.5 \%$ and $25.7 \%$ in high SB and low SB user sites, respectively. Regarding hospital discharge rate, a prevalence of $5.3 \%$ was reported in the high SB user sites compared to $3 \%$ in the "low SB user" sites. In addition, $5.3 \%$ of high SB users achieved a favorable neurological outcome compared to $2.1 \%$ in the low SB user sites [12].

Stiell et al. conducted an observational cohort study in 1995 and reported that SB did not have a significant association with survival. However, the authors noted that the timing of drug administration could be an important factor [28]. Aufderheide et al. reviewed 619 cardiac arrest patients and reported that the survival rate was comparable between SB and control. However, base changes were significantly improved in the 15- to 20-min CPR time interval [16]. Delooz and Lewi conducted a retrospective data analysis in 1989 and reported that $\mathrm{SB}>1 \mathrm{mEq} / \mathrm{kg}$ was associated with poor outcome [29].

\section{Discussion}

Our results showed that SB was not superior to the control group in terms of survival to discharge and return of spontaneous circulation. Moreover, SB administration was associated with lower rates of sustained ROSC and good neurological outcomes than the control group. These findings discourage the use of $\mathrm{SB}$ in OHCA patients.

The onset of SB use in CPR originated in the 1960s from physiological sense, assuming that the resulting acidosis from ischemic injury would prevent successful resuscitation [30]. However, Levine has concluded that in some situations, acidosis may actually be protective [31]. Moreover, several later studies failed to show significant benefits for SB in cardiac arrest $[16,28]$, along with the potential adverse effects as reduction of systemic vascular resistance, compromised coronary flow, hypernatremia, and hyperosmolarity. Therefore, SB administration was

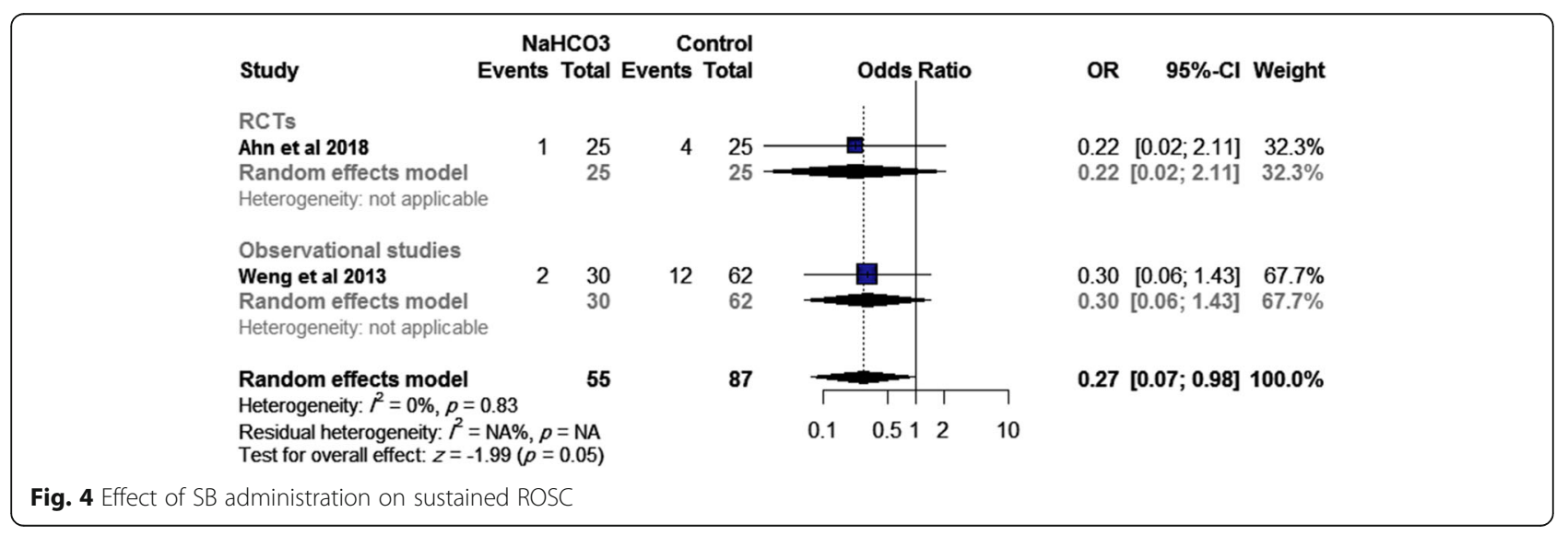




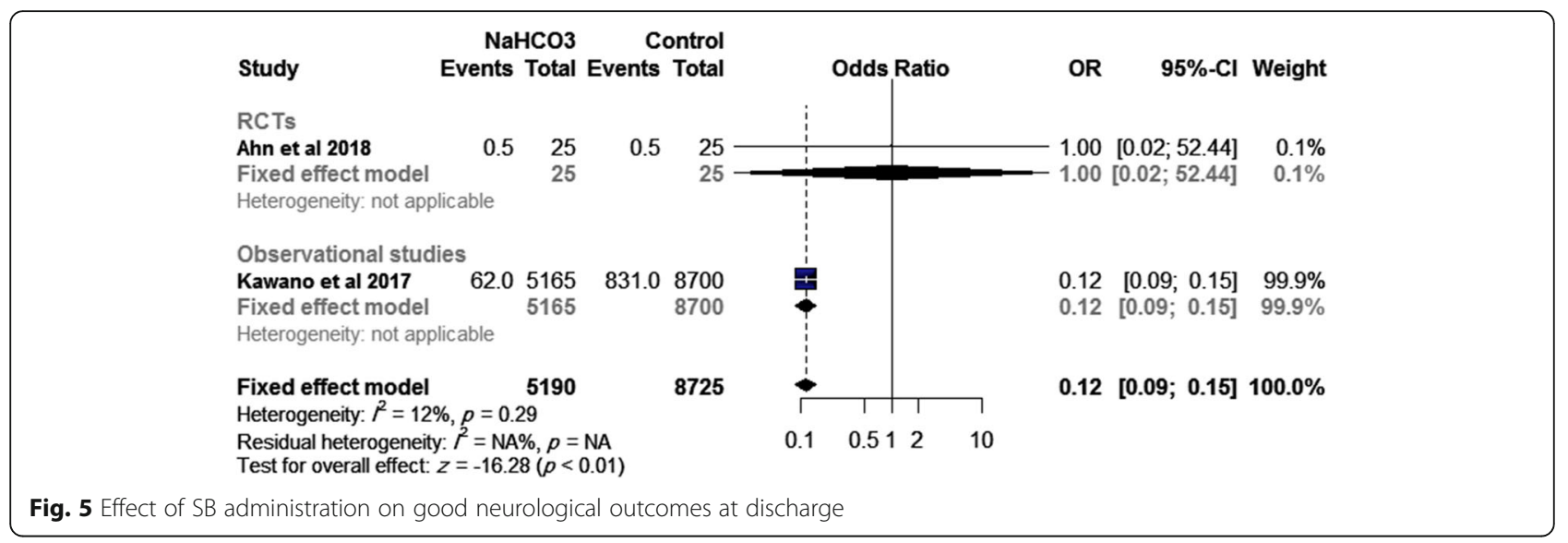

classified as class III status (inappropriate, without scientific evidence of efficacy) for CPR [32].

In 2010, the American Heart Association released resuscitation guidelines that recommended against the routine use of $\mathrm{SB}$ in $\mathrm{CPR}$, except in patients with metabolic acidosis, hyperkalemia, or their arrest is caused by tricyclic antidepressant overdose [10]. In patients with OHCA, CPR is usually protracted, and the occurrence of metabolic acidosis is more frequent than in-hospital cardiac arrest. These guidelines were not updated in the 2015 version [11]. However, the adherence to these guidelines is not optimal. Authors of the BRCT-III trial showed that clinicians do not consider the pre-ALS hypoxia time (the major contributor to metabolic acidosis in cardiac arrest) when deciding to administer SB. They called upon guideline developers to emphasize the importance of pre-ALS hypoxia time and be more specific in determining protracted CPR efforts [27].

Despite this progress, the issue remains controversial. Some recent studies were published on the topic, advocating or negating the benefit of SB administration in OHCA $[13,21,23,24]$, while a recently published systematic review and meta-analysis included 6 observational studies that showed the same results where SB use was not associated with improvement in ROSC or survival-to-discharge rates in cardiac resuscitation [33]. The results of this analysis extend the current guidelines that $\mathrm{SB}$ administration in OHCA is not superior to control in terms of efficacy. To investigate whether the prevalence of retrospective studies affects the results of the analysis, we performed a subgroup analysis based on the study design. The results of the subgroup analyses were consistent with the overall analysis in most outcomes, except for sustained ROSC and achievement of good neurological outcomes. Moderate to significant heterogeneity was observed in most outcomes. This may be related to the different $\mathrm{SB}$ administration protocols.

\section{Limitations}

Some limitations to this meta-analysis should be highlighted. First, the majority of the included studies were observational in nature, which is liable to potential confounders. Second, moderate to significant heterogeneity was observed in most outcomes. This may be related to the different SB administration protocols with different timing of administration and routes. Several studies suggested that the protocol and earlier timing of SB administration factor in the resulting efficacy; however, the optimal protocol for SB administration in cardiac arrest remains unconfirmed [27, 28]. Similarly, Chung et al. noted that the beneficial effects of SB were dose-dependent; higher doses $(>100 \mathrm{ml}$ ) were associated with higher rates of ROSC [25].

\section{Conclusion}

The results of this meta-analysis-based on the published evidence-showed that the use of SB was not associated with improvement in survival to discharge, rate of ROSC, rate of sustained ROSC, and good neurological outcomes at hospital discharge. Until further evidence and characterization of the potentially useful dose and timing of SB administration are available, clinicians and emergency responders are not advised to routinely administer SB in OHCA patients.

\section{Abbreviations}

ALS: Advanced life support; OHCA: Out-of-hospital cardiac arrest; ROSC: Return of spontaneous circulation; CPR: Cardiopulmonary resuscitation; SB: Sodium bicarbonate 


\section{Supplementary Information}

The online version contains supplementary material available at https://doi. org/10.1186/s12245-021-00344-x.

\section{Additional file 1.}

\section{Acknowledgements}

None.

\section{Authors' contributions}

MA: conceptualization, methodology, project administration, validation, resources, supervision. HA: data curation, writing - original draft preparation, visualization, investigation, software. The authors read and approved the final manuscript.

\section{Funding}

None.

\section{Availability of data and materials}

All data generated or analyzed during this study are included in this published article and its supplementary information files.

\section{Declarations}

\section{Competing interest}

The authors declare that they have no competing interests.

\section{Ethics approval and consent to participate}

Not applicable.

\section{Consent for publication}

Not applicable.

\section{Author details}

'Department of emergency and critical care medicine, College of Medicine, Imam Abdulrahman Bin Faisal University, Alkhobar, Saudi Arabia.

${ }^{2}$ Department of Critical Care Medicine, King Fahad Hospital of the University, Alkhobar, Saudi Arabia.

Received: 7 January 2021 Accepted: 22 March 2021

Published online: 13 April 2021

\section{References}

1. Neumar RW, Otto CW, Link MS, Kronick SL, Shuster M, Callaway CW, et al. Part 8: adult advanced cardiovascular life support: 2010 American Heart Association Guidelines for Cardiopulmonary Resuscitation and Emergency Cardiovascular Care. Circulation. 2010;122(18_suppl_3):S729-67. https://doi. org/10.1161/CIRCULATIONAHA.110.970988.

2. Roger $\mathrm{L}, \mathrm{Go}$ AS, Lloyd-Jones DM, Adams R, Berry JD, Brown TM, et al. Heart disease and stroke statistics-2011 update: a report from the American Heart Association. Circulation. 2011;123(4):e18-e209. https//doi.org/10.1161/ClR.0b013e3182009701.

3. McNally B, Robb R, Mehta M, Vellano K, Valderrama AL, Yoon PW, et al. Outof-hospital cardiac arrest surveillance --- Cardiac Arrest Registry to Enhance Survival (CARES), United States, October 1, 2005--December 31, 2010. MMWR Surveill Summ. 2011;60:1-19.

4. Standards for cardiopulmonary resuscitation (CPR) and emergency cardiac care (ECC). 3. Advanced life support. JAMA. 1974:227(Suppl):852-60.

5. Batenhorst RL, Clifton GD, Booth DC, Hendrickson NM, Ryberg ML. Evaluation of 516 cardiopulmonary resuscitation attempts. Am J Hosp Pharm. 1985;42:2478-83.

6. Standards and guidelines for cardiopulmonary resuscitation (CPR) and emergency cardiac care (ECC), et al. JAMA. 1986;255:2905-89.

7. Guidelines for cardiopulmonary resuscitation and emergency cardiac care. Emergency Cardiac Care Committee and Subcommittees, American Heart Association. Part III. Adult advanced cardiac life support. JAMA. 1992;268:2199-241.

8. Guidelines 2000 for Cardiopulmonary Resuscitation and Emergency Cardiovascular Care. Part 6: advanced cardiovascular life support: section 6: pharmacology II: agents to optimize cardiac output and blood pressure. The American Heart Association in collabor. Circulation. 2000;102:1129-35.
9. Kette F, Weil MH, Gazmuri RJ. Buffer solutions may compromise cardiac resuscitation by reducing coronary perfusion presssure. JAMA. 1991;266(15): 2121-6. https://doi.org/10.1001/jama.1991.03470150093037.

10. Vanden Hoek TL, Morrison L, Shuster M, Donnino M, Sinz E, Lavonas EJ, et al. Part 12: cardiac arrest in special situations: 2010 American Heart Association Guidelines for cardiopulmonary resuscitation and emergency cardiovascular care. Circulation. 2010;122(18_suppl_3):S829-61. https://doi. org/10.1161/CIRCULATIONAHA.110.971069.

11. Lavonas EJ, Drennan IR, Gabrielli A, Heffner AC, Hoyte CO, Orkin AM, et al. Part 10: special circumstances of resuscitation. Circulation. 2015;132(18 suppl 2):S501-18. https://doi.org/10.1161/CIR.0000000000000264.

12. Bar-Joseph G, Abramson NS, Kelsey SF, Mashiach T, Craig MT, Safar P, Brain Resuscitation Clinical Trial III (BRCT III) Study Group. Improved resuscitation outcome in emergency medical systems with increased usage of sodium bicarbonate during cardiopulmonary resuscitation. Acta Anaesthesiol Scand. 2005;49(1):6-15. https://doi.org/10.1111/j.1399-6576.2005.00572.x.

13. Kim J, Kim K, Park J, Jo YH, Lee JH, Hwang JE, et al. Sodium bicarbonate administration during ongoing resuscitation is associated with increased return of spontaneous circulation. Am J Emerg Med. 2016;34(2):225-9. https://doi.org/10.1016/j.ajem.2015.10.037.

14. Dybvik T, Strand T, Steen PA. Buffer therapy during out-of-hospital cardiopulmonary resuscitation. Resuscitation. 1995;29(2):89-95. https://doi. org/10.1016/0300-9572(95)00850-S

15. Vukmir RB, Katz L, Sodium Bicarbonate Study Group. Sodium bicarbonate improves outcome in prolonged prehospital cardiac arrest. Am J Emerg Med. 2006;24(2):156-61. https://doi.org/10.1016/j.ajem.2005.08.016.

16. Aufderheide TP, Martin DR, Olson DW, Aprahamian C, Woo JW, Hendley GE, et al. Prehospital bicarbonate use in cardiac arrest: a 3-year experience. Am J Emerg Med. 1992;10(1):4-7. https://doi.org/10.1016/0735-6757(92)90115-E.

17. Higgins JP, Green S. Cochrane Handbook for Systematic Reviews of intervemntions; 2008.

18. Moher D, Liberati A, Tetzlaff J, Altman DG. Preferred reporting items for systematic reviews and meta-analyses: the PRISMA statement. PLoS Med. 2009;6(7):e1000097. https://doi.org/10.1371/journal.pmed.1000097.

19. JPT $H$, Altman DG, Gotzsche PC, Juni $P$, Moher D, Oxman AD, et al. The Cochrane Collaboration's tool for assessing risk of bias in randomised trials. BMJ. 2011;343(oct18 2):d5928. https://doi.org/10.1136/bmj.d5928.

20. Stang A. Critical evaluation of the Newcastle-Ottawa scale for the assessment of the quality of nonrandomized studies in meta-analyses. Eur J Epidemiol. 2010;25(9):603-5. https://doi.org/10.1007/s10654-010-9491-z.

21. Ahn S, Kim Y-J, Sohn CH, Seo DW, Lim KS, Donnino MW, et al. Sodium bicarbonate on severe metabolic acidosis during prolonged cardiopulmonary resuscitation: a double-blind, randomized, placebo-controlled pilot study. J Thorac Dis. 2018;10(4):2295-302. https://doi.org/10.21037/jtd.2018.03.124.

22. Weaver WD, Fahrenbruch CE, Johnson DD, Hallstrom AP, Cobb LA, Copass MK. Effect of epinephrine and lidocaine therapy on outcome after cardiac arrest due to ventricular fibrillation. Circulation. 1990;82(6):2027-34. https:// doi.org/10.1161/01.CIR.82.6.2027.

23. Chen $Y-C$, Hung M-S, Liu C-Y, Hsiao C-T, Yang Y-H. The association of emergency department administration of sodium bicarbonate after out of hospital cardiac arrest with outcomes. Am J Emerg Med. 2018;36(11):19982004. https://doi.org/10.1016/j.ajem.2018.03.010.

24. Kawano T, Grunau B, Scheuermeyer FX, Gibo K, Dick W, Fordyce CB, et al. Prehospital sodium bicarbonate use could worsen long term sunvival with favorable neurological recovery among patients with out-of-hospital cardiac arrest. Resuscitation. 2017;1 19:63-9. https://doi.org/10.1016/j.resuscitation.2017.08.008.

25. Chung C, Lui C, Tsui K. Role of sodium bicarbonate in resuscitation of outof-hospital cardiac arrest. Hong Kong J Emerg Med. 2015;22(5):281-90. https://doi.org/10.1177/102490791502200504.

26. Weng Y-M, Wu S-H, Li W-C, Kuo C-W, Chen S-Y, Chen J-C. The effects of sodium bicarbonate during prolonged cardiopulmonary resuscitation. Am J Emerg Med. 2013;31(3):562-5. https://doi.org/10.1016/j.ajem.2012.11.001.

27. Bar-Joseph G, Abramson NS, Jansen Williams L, Kelsey SF, Mashiach T, Craig $M T$, et al. Clinical use of sodium bicarbonate during cardiopulmonary resuscitation--is it used sensibly? Resuscitation. 2002;54:47-55.

28. Stiell IG, Wells GA, Hebert PC, Laupacis A, Weitzman BN. Association of drug therapy with sunvival in cardiac arrest: limited role of advanced cardiac life support drugs. Acad Emerg Med. 1995;2(4):264-73. https:/doi.org/10.1111/.1553-2712.1995.tb03220x.

29. Delooz HH, Lewi PJ. Are inter-center differences in EMS-management and sodiumbicarbonate administration important for the outcome of CPR? The Cerebral Resuscitation Study Group. Resuscitation. 1989;17(Suppl):S161-72 discussion S199-206. 
30. Gazmuri RJ. Buffer treatment for cardiac resuscitation: putting the cart before the horse? Crit Care Med. 1999;27(5):875-6. https://doi.org/10.1097/00003246-1 99905000-00014.

31. Levine RL. Ischemia: from acidosis to oxidation. FASEB J. 1993;7(13):1242-6. https://doi.org/10.1096/fasebj.7.13.8405809.

32. Christenson JM, Solimano AJ, Williams J, Connolly B, Monik L, Erb-Campbell $H$, et al. The new American Heart Association guidelines for cardiopulmonary resuscitation and emergency cardiac care: presented by the Emergency Cardiac Care Subcommittee of the Heart and Stroke Foundation of Canada. CMAJ. 1993;149:585-90.

33. Wu KH, Chang CY, Chen YC, Chang CP, Hsiao CT, Weng HH. Effectiveness of sodium bicarbonate administration on mortality in cardiac arrest patients: a systematic review and meta-analysis. J Emerg Med. 2020;59(6):856-64. https://doi. org/10.1016/j.jemermed.2020.08.012.

\section{Publisher's Note}

Springer Nature remains neutral with regard to jurisdictional claims in published maps and institutional affiliations.

Ready to submit your research? Choose BMC and benefit from:

- fast, convenient online submission

- thorough peer review by experienced researchers in your field

- rapid publication on acceptance

- support for research data, including large and complex data types

- gold Open Access which fosters wider collaboration and increased citations

- maximum visibility for your research: over $100 \mathrm{M}$ website views per year

At BMC, research is always in progress.

Learn more biomedcentral.com/submissions 